Institute by generously contributing to its funds. The Comte de Briey, who has served as a member of the Institute's Consultative Committee, was able, during a recent visit to Belgium, to give an account of the Institute's war-time activities and future plans to the Belgian Colonial Minister and the Directors of the Institut Royal Colonial Belge and the Université Coloniale de Belgique.

Opportunities for the closer participation of Africanists in the U.S.A. are being actively explored. Dr. Edwin Smith provided the Institute with a valuable review of the possibilities on his return from the United States, in the light of which American members have been invited to give us their views. A number of constructive suggestions and offers of assistance have been received from them in response to this inquiry.

\title{
Handbook of African Languages
}

The grant from the British Colonial Office towards the work on the Handbook of African Languages has been renewed for a second year; Miss Bryan's article in this number of Africa will give some indication of the problems to be faced in this undertaking. A bibliographical and lexicographical study of recent works on Bantu languages, by Professor Doke of Witwatersrand University, is now in the press, and further publications in connexion with the Handbook are in preparation.

\section{Research in the British Cameroons}

A FIRST report has been received from Dr. Kaberry outlining her plans for the conduct of her study on the position of women in the British Cameroons (Bamenda division) (see Africa, January 1945). For the present she is basing her work on Kimbaw, investigating social conditions there and in the surrounding villages.

\section{Ethnographic Survey of Africa}

Tre Institute has undertaken the preparation of an Ethnographical survey of Africa. The importance, for scientific research and for social development and welfare, of a comprehensive survey of the ethnic groupings, distributions and salient social conditions of the peoples of Africa has been urged in the Institute itself and elsewhere for a number of years. Recently the need for an organization which would assemble, collate and make available the wealth of existing but uncoordinated material has been more acutely realized in connexion with plans for economic and general social development after the war. In the absence of such a survey much of the extant material is virtually inaccessible to scholars and governments alike. In addition to published work there is, in the governmental archives and the records of private institutions, much valuable material which for lack of organization rather than from any desire to restrict access has hitherto remained unavailable.

The Survey will, it is hoped, be of direct value to all Africanists and will also help to ensure that the limited funds and personnel available for further research are directed where they are most needed and most likely to produce results of scientific and practical value. Its object is to present a systematic outline of existing knowledge with a critical bibliography of available sources and so to provide reliable data of value to students and those professionally concerned with African affairs.

The Institute has received a grant for a five-year period from the British Colonial Development and Welfare Fund towards the cost of the Survey and has welcomed assurances of readiness to co-operate from both French and Belgian official and scientific organizations. In West Africa the work will be carried out in close collaboration with the I.F.A.N. which is undertaking a 'Répertoire des Populations' in French West Africa. While it is necessary to envisage an inquiry extending over some considerable time, and to frame plans accordingly, provisional results will be made available as the Survey progresses. 